\title{
TNFAIP3 Gene Mutation
}

National Cancer Institute

\section{Source}

National Cancer Institute. INFAIP3 Gene Mutation. NCI Thesaurus. Code C156751.

A change in the nucleotide sequence of the TNFAIP3 gene. 